\title{
Ohjaustyön käytännön ja teorian yhdistäminen innostaa vapaan sivistystyön toimijoita'
}

Tytti Pantsar

Suomen Kansanopistoyhdistys - Finlands Folkhögskolförening ry on Suosina 2018-2020 toiminut koordinaattorina Sosiaalipedagoginen ohjaus vapaan sivistystyön oppilaitoksissa -hankkeessa. Hankkeen yhteistyökumppaneina ovat toimineet Itä-Suomen yliopisto, Bildningsalliansen rf sekä Opintokeskukset ry. Lisäksi mukana on ollut joukko kansanopistoja ja opintokeskuksia. Hanketta on rahoittanut Opetushallitus.

Hankkeen tavoitteena on ollut kehittää vapaan sivistystyön oppilaitosten erityisesti maahanmuuttajataustaisten opiskelijoiden ohjausta siten, että ohjaus tukee kokonaisvaltaista kotoutumista, työllistymismahdollisuuksia ja arjen kansalaisuuden rakentumista. Hankkeessa tuotettiin ohjauksen prosessimalli oppilaitoksissa työskentelevien työn tueksi. Hanke on innostanut vapaan sivistystyön toimijoita yhdessä Itä-Suomen yliopiston kanssa pohtimaan sivistyksen ja sivistyspedagogiikan lähtökohtia kotoutumisen kontekstissa.

\footnotetext{
${ }^{1}$ Puheenvuoro 29.10.2020 verkossa järjestetyssä Maahanmuuttajaopiskelijan kohtaaminen ohjaustyössä -seminaarissa, joka oli Sosiaalipedagoginen ohjaus vapaan sivistystyön oppilaitoksissa -hankkeen päätösseminaari.
} 
Aluksi hankkeessa toteutettiin esiselvitys siitä, miten oppilaitoksissa kotoutujien ohjaus hahmotetaan, minkälaisia ohjaustarpeita maahanmuuttajilla on ja minkälaisia ohjausmenetelmiä käytetään. Eine Pakarisen (2020) laatimasta esiselvityksestä voi lukea, että toimijat ovat pohtineet ohjausta monipuolisesti ja tunnistaneet sen merkityksen todella laajasti.

Esiselvityksen mukaan toimijat ajattelevat, että ohjauksella voidaan tukea maahanmuuttajien opiskeluvalmiuksia ja oppimaan oppimisen taitoja. Toimijat näkivät, että ohjauksella autetaan maahanmuuttajaa ottamaan vastuuta omasta oppimisestaan ja rohkaistaan häntä tekemään itsenäisiä päätöksiä. Onnistuneella ohjauksella voidaan myös vahvistaa maahanmuuttajan itsetuntoa ja rakentaa hänen identiteettiään. Esiselvitys toi näkyville ja yhteisesti kehitettäväksi hiljaisen tiedon ohjaustyöstä.

Esiselvityksen, hankkeessa toteutettujen ohjauskokeilujen ja tutkimuksellisuuden yhdistelmänä Itä-Suomen yliopisto laati sosiaalipedagogisen ohjauksen mallin vapaan sivistystyön toimijoiden kotoutumista edistävän ohjauksen ja koulutuksen tueksi. Hankkeen aikana punoutui yhteen hiljaisen tiedon esiin nostaminen sivistystyön käytännöstä ja sosiaalipedagoginen teoria. Sivistyspedagogiikan keskeiset lähtökohdat ovat kiinteästi läsnä kansanopistojen ja opintokeskusten ohjaustyössä. Tutkimuksellinen lähestymistapa toi ne yhteisesti tarkasteltaviksi. Näkemykseni mukaan sosiaalipedagogisen ohjauksen malli systematisoi, käsitteellistää ja jalostaa ohjaustyötä ja antaa suunnan kehittämistyölle.

Sosiaalipedagogisen ohjauksen mallissa kiteytyvät sivistyksen ydinasiat, ajateltiinpa sivistystä prosessina tai päämääränä: aito kohtaaminen, ihmisen näkeminen ainutlaatuisena ja arvokkaana sekä tasavertainen dialogi. Erityisen arvokas on mielestäni mallin ajatus siitä, että ohjaaja tukee opiskelijaa toivossa, tulevaisuususkossa ja rohkeudessa.

Mallissa on läsnä sivistyksen prosessiin aiemmassakin tutkimuksessa liitetty ajatus jokaisen kasvamisesta täyteen potentiaaliin. Erityisen tärkeää on tuoda tämä näkökulma osaksi nykyistä kotoutumisesta käytävää yhteiskunnallista keskustelua. Kotoutumisesta käytävää keskustelua leimaavat asettuminen yhteiskuntaan ja työllistymisen tavoite. Sosiaalipedagogisessa ohjauksen mallissa ihminen on kokonaisuus, jonka kasvua täyteen potentiaaliin tuetaan laajasti. Siten syntyy elementtejä kunkin omanlaisen työuran tai opiskelupolun hahmottamiseen.

Hankkeen aikana eduskunnan tarkastusvaliokunta linjasi, että vapaan sivistystyön roolia kotoutumisen edistämisessä tulee lisätä. Hankkeessa luotu sosiaalipedagogisen ohjauksen malli on keskeinen vapaan sivis- 
tystyön roolin ja tehtävien hahmottamisessa. Kansanopistoissa ja opintokeskuksissa jokainen voidaan huomioida kokonaisvaltaisesti omana itsenään ja jokaisen kasvua voidaan tukea monipuolisesti. Tämä on oleellista kotoutujan toimintakyvyn, osallisuuden ja osallistumisen sekä laajemmin yhdenvertaisuuden ja yhteiskuntarauhan näkökulmasta. Hankkeessa mallinnetut asiat ovat keskeisesti sellaisia, joita voimme pitää esillä vapaan sivistystyön osaamisena, kun otamme kantaa kotoutumispoliittisen selonteon ja valtion kotouttamisohjelman laatimisprosessiin.

Näkökulma on tässä hankkeessa kotoutuminen, mutta ajattelen, että syntyneet periaatteet ja toimintamallit sopivat kaikille sivistystoimijoille. Nyt pohditaan sitä, miten vapaan sivistystyön oppilaitokset voivat olla mukana meneillään olevassa jatkuvan oppimisen uudistuksessa. Tärkeintä on löytää keinoja saada oppimisen pariin myös ne, jotka eivät osallistu, halua osallistua tai kiinnity opintoihin. Kehitetty ohjausmalli tarjoaa hyviä lähtökohtia tähän työhön. Sosiaalipedagogisen ohjauksen malli on hyödynnettävissä myös, kun oppivelvollisuusuudistus etenee ja kansanopistot käynnistävät uuden vapaan sivistystyön koulutuksen, jonka tarkoitus on tukea jokaista nuorta löytämään omanlaisensa polku ja ehkäistä syrjäytymistä.

Vapaan sivistystyön oppilaitosten lakisääteisenä tehtävänä on aktiivisen kansalaisuuden edistäminen. Hyvä kotoutuminen on kuulumista ja sitä, että voi olla aktiivinen toimija yhteisössä ja yhteiskunnassa. Sivistyksen teoriaa ja sivistyspedagogiikka aikanaan tutkinut Seppo Niemelä muistutti usein meitä sivistystoimijoita siitä, että aktiivinen kansalaisuus sivistymisen näkökulmasta tarkoittaa, että demokratiaan tarvitaan ihmisiä, joilla on kyky kommunikoida itsenäisesti ja omaehtoisesti, ottaa kantaa ja tehdä päätöksiä sekä toimia. Sosiaalipedagoginen ohjauksen malli tukee tätä ajatusta sivistymisestä ja aktiivisesta kansalaisuudesta. Sellaista ohjausta me ihan kaikki tarvitsemme.

\section{LÄHTEET}

Pakarinen, E. 2020. Selvitys vapaan sivistystyön oppilaitoksissa annetusta ohjauksesta maahanmuuttajille. Helsinki: Suomen Kansanopistoyhdistys. Saatavissa https:// www.kansanopistot.fi/wp-content/uploads/2020/04/SKY_Selvitys_Sosaalipedagoginen_ohjaus_090420_web.pdf (haettu 19.11.2020). 
144 - Sosiaalipedagoginen aikakauskirja, vuosikirja 2020, vol. 21 